\title{
Hemophagocytic Lymphohistiocytosis Presenting as Subacute Meningoencephalitis
}

\author{
Sumeet Rajendra Dhawan • Sunil Natha Jondhale • \\ Jitendra Kumar Sahu • Pratibha Singhi
}

Received: 18 March 2014 / Accepted: 5 June 2014 / Published online: 20 June 2014

(C) Dr. K C Chaudhuri Foundation 2014

To the Editor: A four-year-old boy was brought with $11 \mathrm{~d}$ history of high grade fever, headache, vomiting and irritability. The child was diagnosed as West syndrome at 6 mo of age and successfully treated with adrenocorticotropic hormone therapy. Subsequently, he had few infrequent seizures which were controlled on valproate. On examination, mild pallor, neck stiffness and hepatomegaly were found. Investigations revealed hemoglobin $7.7 \mathrm{~g} / \mathrm{dl}$, platelets $105,000 / \mathrm{mm}^{3}$, total leukocyte count $7700 / \mathrm{mm}^{3}$, neutrophils of $68 \%$, albumin $2.1 \mathrm{~g} / \mathrm{dl}$ and C-reactive protein $262 \mathrm{mg} / \mathrm{L}$. Chest radiograph and contrast enhanced magnetic resonance imaging of brain were normal. Cerebrospinal fluid analysis showed 30 cells $/ \mathrm{mm}^{3}$ (70\% neutrophils), sugar $51 \mathrm{mg} / \mathrm{dl}$, and proteins $69 \mathrm{mg} / \mathrm{dl}$. He was initially treated with ceftriaxone and acyclovir. He continued to have fever and developed pancytopenia, worsening transaminitis and splenomegaly. Investigations showed serum triglycerides $294 \mathrm{mg} / \mathrm{dl}$ (normal $<150 \mathrm{mg} / \mathrm{dl}$ ), fibrinogen level $1.5 \mathrm{~g} / \mathrm{L}$ (normal range $1.5-4 \mathrm{~g} / \mathrm{L}$ ), ferritin $133.4 \mathrm{mcg} / \mathrm{L}$ (normal range $7-140 \mathrm{mcg} / \mathrm{dl}$ ) and 3+ hemophagocytes in the bone marrow. The child was given methylprednisolone pulse therapy followed by oral steroids and he became afebrile after $3 \mathrm{~d}$. On one year follow-up child is asymptomatic.

This case highlights the fact that hemophagocytic lymphohistiocytosis should be considered as diagnostic possibility in a child with subacute meningoencephalitis.

S. R. Dhawan · S. N. Jondhale · J. K. Sahu • P. Singhi $(\triangle)$ Division of Pediatric Neurology, Department of Pediatrics, Postgraduate Institute of Medical Education and Research, Chandigarh 160012, India

e-mail: doctorpratibhasinghi@gmail.com
Although various neurologic symptoms are known, meningo-encephalitic presentation at onset of hemophagocytic lymphohistiocytosis is rare. In a series by Horne et al., $37 \%$ had neurological symptoms such as seizures, cranial nerve palsy, meningismus, altered sensorium, tone abnormalities, and upto $52 \%$ had abnormal cerebrospinal fluid [1]. Persistence of fever, worsening pancytopenia, increasing splenomegaly, worsening triglyceridemia and hypofibrinogenemia should point towards the possibility of hemophagocytic lymphohistiocytosis [2]. This diagnosis is important because of the therapeutic potential. The index case also had West syndrome, which is a unique age dependent epileptic encephalopathy characterised by clustered infantile spasms, hypsarrthymia on electroencephalography. Both entities, being responsive to steroids treatment and having genetic susceptibility, generate hypothesis of possible common pathophysiological link; however this needs to be investigated.

Conflict of Interest None.

Source of Funding None.

\section{References}

1. Horne AC, Trottestam H, Aricò M, Egeler RM, Filipovich AH, Gadner H, et al; Histiocyte Society. Frequency and spectrum of central nervous system involvement in 193 children with haemophagocytic lymphohistiocytosis. Br J Haematol. 2008;140:327-35.

2. Henter JI, Horne A, Aricó M, Egeler RM, Filipovich AH, Imashuku S, et al. HLH-2004: Diagnostic and therapeutic guidelines for hemophagocytic lymphohistiocytosis. Pediatr Blood Cancer. 2007;48:124-31. 